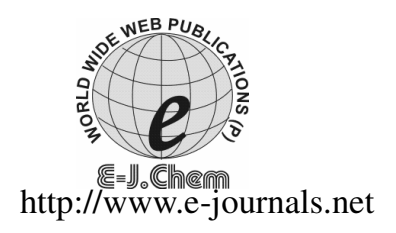

ISSN: 0973-4945; CODEN ECJHAO

E-Journal of Chemistry 2011, 8(2), 782-786

\title{
Determination of Trace Elements, Heavy Metals and Rare Earth Elements in Corn Seeds from Beijing by ICP-MS Simultaneously
}

\author{
ZHANG HONGXING* and RUI YU-KUI \\ *Department of Food Science \\ Beijing Agricultural College, Beijing 102206, China \\ College of Resources and Environmental Sciences \\ China Agricultural University, Beijing 100193, China \\ zhanghx511@gmail.com
}

Received 2 June 2010; Revised 8 November 2010; Accepted 12 November 2010

\begin{abstract}
Food nutrition and food safety have been paid more and more attention, so it is important to find new detecting method. ICP-MS is a good method to detect many elements simultaneously with high accuracy, but detecting more than ten elements simultaneously has little been reported, especially in cereal. Contents of forty elements in corn kernel from Beijing were detected by ICP-MS, we conclude that; 19 elements (Li, I, Co, Ni, Mo, Cs, B, $\mathrm{Mn}, \mathrm{Fe}, \mathrm{Cu}, \mathrm{Zn}, \mathrm{Rb}, \mathrm{Sr}, \mathrm{Ti}, \mathrm{Cd}, \mathrm{Sn}, \mathrm{Tl}, \mathrm{Pb}$ and $\mathrm{Cr}$ ) in corn can be precisely and accurately determined simultaneously. As, $\mathrm{Se}, \mathrm{Bi}, \mathrm{Th}, \mathrm{U}, \mathrm{Sb}, \mathrm{Al}$ and rare earth elements could not be precisely detected at this condition, probably due to too low concentrations; Corn from Beijing contains many wholesome trace elements, such as $\mathrm{Mo}, \mathrm{B}, \mathrm{Mn}, \mathrm{Fe}, \mathrm{Cu}, \mathrm{Zn}, \mathrm{Rb}$ and $\mathrm{Sr}$; but the toxic elements little, so it is safe and not polluted.
\end{abstract}

Keywords: Corn, Trace elements, Heavy metals, Rare Earth, Beijing, ICP-MS

\section{Introduction}

Corn is the second cereal crop in China, which is mostly used as food material and feed ${ }^{1}$. With the quick development of industry, the environment where corn grows is being damaged, which has resulted many food safety case, so more and more attention has focused on food safety ${ }^{2}$. Beijing as the capital of China has dramatically developed in the last decades, especially the development of cars and urban construction, which can carry many toxic elements ${ }^{3}$ and these toxic elements could change the contents of other elements in corn, especially the wholesome trace elements, so it is important to study contents of trace elements, heavy metals and rare earth in corn seed. 
Before the application of ICP-MS, the usual methods to detect trace elements, heavy metals and rare earth elements are atomic absorption spectrometry (AAS) ${ }^{4}$ and atomic fluorescence spectrometry (AFS) ${ }^{5}$, which have made great devotions to food nutrition and food safety. But usually many elements need detecting at the same time to determine causes of food safety or environment problem, the method ICP-MS is better than methods AAS and AFS, because ICP-MS has the ability to detect many elements simultaneously and high accuracy $^{6}$.

\section{Experimental}

All the 15 corn samples were grown in Shangzhuang experimental station of China Agricultural University, Beijing. The ICP-MS instrument was the PQ Excell instrument (ELAN DRCII, PE Company, USA) from Central Laboratory, School of Public Health, Peking University.

\section{Sample preparation}

The corn seeds were washed with deionized water three times, then samples were prepared by microwave digestion, detailed methods for which were given by $\mathrm{Shen}^{7}$ with some changes. $0.5 \mathrm{~g}$ Corn seeds were grinded in $1 \%$ nitric acid $8 \mathrm{~mL}$, PTFE was added to the digestion tank, the microwave digestion conditions was shown in Table 1. After cooling the digestion tank, $25 \mathrm{~mL}$ of $1 \%$ nitric acid was added for detection.

Table 1. Microwave digestion temperature control program

\begin{tabular}{cccccc}
\hline Step & $\begin{array}{c}\text { Maximum } \\
\text { power }(\mathrm{W})\end{array}$ & $\begin{array}{c}\text { Climb time, } \\
\min \end{array}$ & $\begin{array}{c}\text { Pressure, } \\
\mathrm{psi}\end{array}$ & $\begin{array}{c}\text { Temperature, } \\
{ }^{\circ} \mathrm{C}\end{array}$ & $\begin{array}{c}\text { Hold time, } \\
\text { min }\end{array}$ \\
\hline 1 & 1250 & 6 & 300 & 120 & 5 \\
2 & 1250 & 8 & 300 & 210 & 10 \\
\hline
\end{tabular}

\section{Instrument parameters}

Instrument parameters were as described in the literature ${ }^{8-9}$, with some modifications, given in Table 2.

Table 2. The operating parameters for ICP-MS

\begin{tabular}{cc}
\hline Method parameters & Value \\
\hline Power (W) & 1350 \\
Plasma flow, L/min & 13.0 \\
Nebulizer flow, L/min & 1.00 \\
Auxiliary flow, L/min & 1.25 \\
Sampling depth, mm & 2.0 \\
Scanning times & 160 \\
Exit plate (V) & 0 \\
Pump rate (rpm) & 20 \\
Rinse time (s) & 10 \\
Replicates & 5 \\
Replicate read time (s) & 8 \\
Instrument stabilization (s) & 8 \\
Sample delay uptake (s) & 60 \\
\hline
\end{tabular}




\section{Results and Discussion}

\section{Precision, accuracy and limits of detection of method}

The relative standard deviation of most elements is below $10 \%$, especially the wholesome trace elements (Table 3) and toxic elements (Table 4). But the relative standard deviation of elements $\mathrm{As}, \mathrm{Se}, \mathrm{Bi}, \mathrm{Th}, \mathrm{U}, \mathrm{Sb}$ and $\mathrm{Al}$ are higher than $15 \%$, which could be interfered by other elements. Relative standard deviations of elements rare earth elements (La, Ce, Pr, Nd, Sm, Eu, Gd, Tb, Dy, Ho, Er, Tm and Yb) are all higher than $20 \%$ (Table 5), so it is not a good methods to simultaneously at this condition. From these data 19 elements ( $\mathrm{Li}, \mathrm{I}, \mathrm{Co}, \mathrm{Ni}, \mathrm{Mo}, \mathrm{Cs}, \mathrm{B}, \mathrm{Mn}, \mathrm{Fe}, \mathrm{Cu}, \mathrm{Zn}, \mathrm{Rb}, \mathrm{Sr}, \mathrm{Ti}, \mathrm{Cd}$, $\mathrm{Sn}, \mathrm{Tl}, \mathrm{Pb}$ and $\mathrm{Cr}$ ) can be precisely determined simultaneously. Recoveries of all elements mostly range from $90 \%$ to $110 \%$, which showed that this method is accurate to determine these elements (Table 3-5).

Concentration of trace elements, heavy metals and rare earth elements in corn seeds

From the tables Table 3-5, corn from Beijing contains many wholesome trace elements, such as $\mathrm{Mo}, \mathrm{B}, \mathrm{Mn}, \mathrm{Fe}, \mathrm{Cu}, \mathrm{Zn}, \mathrm{Rb}$ and $\mathrm{Sr}$, especially the contents of $\mathrm{B}, \mathrm{Mn}$, $\mathrm{Fe}, \mathrm{Cu}, \mathrm{Zn}, \mathrm{Rb}$ and $\mathrm{Sr}$ are higher than $2.80 \mu \mathrm{g} / \mathrm{g}$; but the toxic elements and rare earth elements are mostly below $50 \mathrm{ng} / \mathrm{g}$. Reason for the low levels of toxic elements and rare earth elements may be due to; (i) concentrations of these elements are low in soil or environment; (ii) the forms of these elements in soil are not active and difficult to absorb by plant. All these data showed that corn is a nutritional and healthy food for human

Table 3. Contents and relative standard deviations of trace elements

\begin{tabular}{cccc}
\hline Element & Content & RSD, \% & Recovery, \% \\
\hline $\mathrm{Li}$ & $6.42 \mathrm{ng} / \mathrm{g}$ & 8.65 & 98.76 \\
$\mathrm{I}$ & $14.09 \mathrm{ng} / \mathrm{g}$ & 4.72 & 97.63 \\
$\mathrm{Co}$ & $6.58 \mathrm{ng} / \mathrm{g}$ & 3.54 & 102.91 \\
$\mathrm{Ni}$ & $123.34 \mathrm{ng} / \mathrm{g}$ & 2.93 & 99.74 \\
$\mathrm{Se}$ & $27.20 \mathrm{ng} / \mathrm{g}$ & 46.6 & 108.15 \\
$\mathrm{Mo}$ & $759.02 \mathrm{ng} / \mathrm{g}$ & 1.63 & 101.27 \\
$\mathrm{Cs}$ & $51.97 \mathrm{ng} / \mathrm{g}$ & 6.14 & 100.91 \\
$\mathrm{Bi}$ & $0.06 \mathrm{ng} / \mathrm{g}$ & 39.33 & 94.51 \\
$\mathrm{Th}$ & $0.80 \mathrm{ng} / \mathrm{g}$ & 40.10 & 106.34 \\
$\mathrm{U}$ & $0.20 \mathrm{ng} / \mathrm{g}$ & 16.8 & 99.46 \\
$\mathrm{~B}$ & $2149.12 \mathrm{ng} / \mathrm{g}$ & 9.33 & 105.21 \\
$\mathrm{Mn}$ & $4.40 \mu \mathrm{g} / \mathrm{g}$ & 4.18 & 100.54 \\
$\mathrm{Fe}$ & $28.89 \mu \mathrm{g} / \mathrm{g}$ & 3.92 & 98.64 \\
$\mathrm{Cu}$ & $2.86 \mu \mathrm{g} / \mathrm{g}$ & 12.27 & 103.24 \\
$\mathrm{Zn}$ & $15.03 \mu \mathrm{g} / \mathrm{g}$ & 1.88 & 101.35 \\
$\mathrm{Rb}$ & $5.91 \mu \mathrm{g} / \mathrm{g}$ & 2.04 & 104.61 \\
$\mathrm{Sr}$ & $6.02 \mu \mathrm{g} / \mathrm{g}$ & 6.56 & 99.61 \\
\hline
\end{tabular}


Table 4. Contents and relative standard deviations of toxic elements

\begin{tabular}{cccc}
\hline Element & Content, ng/g & RSD/\% & Recovery, \% \\
\hline $\mathrm{Ti}$ & 353.58 & 11.95 & 89.61 \\
$\mathrm{Cd}$ & 32.31 & 1.98 & 110.34 \\
$\mathrm{Sn}$ & 0.36 & 13.08 & 107.59 \\
$\mathrm{Sb}$ & 0.72 & 65.9 & 104.21 \\
$\mathrm{Tl}$ & 0.38 & 7.57 & 94.67 \\
$\mathrm{~Pb}$ & 38.15 & 4.98 & 100.61 \\
$\mathrm{Cr}$ & 338.75 & 2.08 & 103.54 \\
$\mathrm{Hg}$ & 0.00 & - & 92.64 \\
$\mathrm{As}$ & 8.03 & 23.9 & 95.46 \\
$\mathrm{Al}$ & $6.09 \mu \mathrm{g} / \mathrm{g}$ & 16.4 & 97.81 \\
\hline
\end{tabular}

Table 5. Contents and relative standard deviations of rare earth elements

\begin{tabular}{cccc}
\hline Element & Content, ng/g & RSD\% & Recovery, \% \\
\hline $\mathrm{La}$ & 4.50 & 29.0 & 98.89 \\
$\mathrm{Ce}$ & 8.00 & 27.5 & 105.61 \\
$\mathrm{Pr}$ & 0.91 & 29.5 & 107.51 \\
$\mathrm{Nd}$ & 3.86 & 27.6 & 95.68 \\
$\mathrm{Sm}$ & 0.71 & 28.7 & 100.34 \\
$\mathrm{Eu}$ & $<0.100$ & - & 105.21 \\
$\mathrm{Gd}$ & 0.65 & 28.6 & 109.28 \\
$\mathrm{~Tb}$ & $<0.100$ & - & 94.87 \\
$\mathrm{Dy}$ & 0.36 & 35.07 & 89.67 \\
$\mathrm{Ho}$ & $<0.100$ & - & 105.62 \\
$\mathrm{Er}$ & 0.14 & 18.84 & 99.46 \\
$\mathrm{Tm}$ & $<0.100$ & - & 102.21 \\
$\mathrm{Yb}$ & $<0.100$ & - & 105.39 \\
\hline
\end{tabular}

\section{Conclusion}

19 Elements (Li, I, Co, Ni, Mo, Cs, B, Mn, Fe, Cu, Zn, Rb, Sr, Ti, Cd, Sn, Tl, Pb and Cr) in corn can be precisely determined simultaneously. As, Se, Bi, Th, U, Sb and Al could not be precisely detected at this condition, the cause should be other element ${ }^{10}$, so we should select another condition or method, rare earth elements could not neither be precisely detected at this condition, the cause should be that their concentrations are too low, rare earth elements should be condensed before detection. Corn from Beijing contains many wholesome trace elements, such as $\mathrm{Mo}, \mathrm{B}, \mathrm{Mn}, \mathrm{Fe}, \mathrm{Cu}, \mathrm{Zn}, \mathrm{Rb}$ and $\mathrm{Sr}$, but little toxic elements, so it is safe and not polluted.

\section{Acknowledgment}

The authors appreciate the financial support of the Programs of Beijing Emphasis Construction Subjects (No. PXM2009_014207_078172). We thank Ms. Wang Xiaoyan (School of public health, Peiking University, China) for help detecting. 


\section{References}

1. $\quad$ Dong S T and Zhang J W, J Maize Sci., 2008, 16(4), 18-20, 25.

2. $\quad$ Chen C H, Liu P and Liu X J, Food Eng., 2007, 4, 3-7.

3. $\quad \mathrm{Fu} \mathrm{H}, \mathrm{Wu} \mathrm{Y} \mathrm{H}$ and Wei L H, J Agro-Environ Sci., 2006, 25(1), 182-185.

4. Yang Y, Hou X Y, Wang S J, Jia Q L, Li Z and Guo Z K, Spectrosc Spect Anal., 2004, 24(12), 1672-1675.

5. Zhao S L, Duan M, Sun X T, Wang B and Wen R Y, J Triticeae Crop., 2004, 24(1), 66-69.

6. Richard K, Marketa B, Barbara B, Jan P, Oto Mestek and Jana K, Food Chem., 2006, 99, 158-167.

7. Shen X Y, Xie C X, Deng W P and Qian X Y, Phys Test Chem Anal (Part B: Chem Anal., 2009, 45(12), 1428-1429.

8. Rui Y K, Yu Q Q, Jin Y H, Guo J and Luo Y B, Spectrosc Spect Anal., 2007, 27(5), 1015-1017.

9. Zhang H X, Xu F and Rui Y K, Asian J Chem., 2010, 22(6), 4777-4780.

10. Hu S H, Wang X J, Ge W, Li A R, Jin L L and Wang X H, Chin J Anal Chem., 2004, 32(9), 1139-1144. 


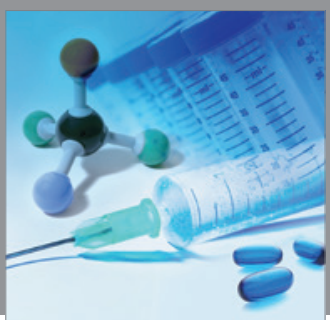

International Journal of

Medicinal Chemistry

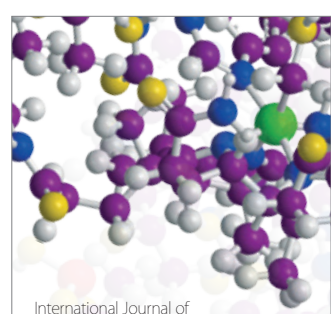

Carbohydrate Chemistry

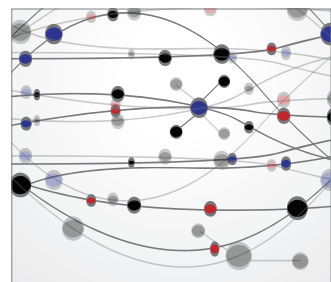

The Scientific World Journal
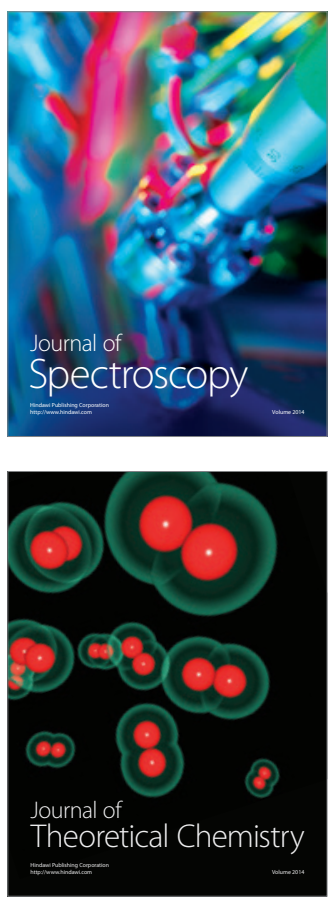
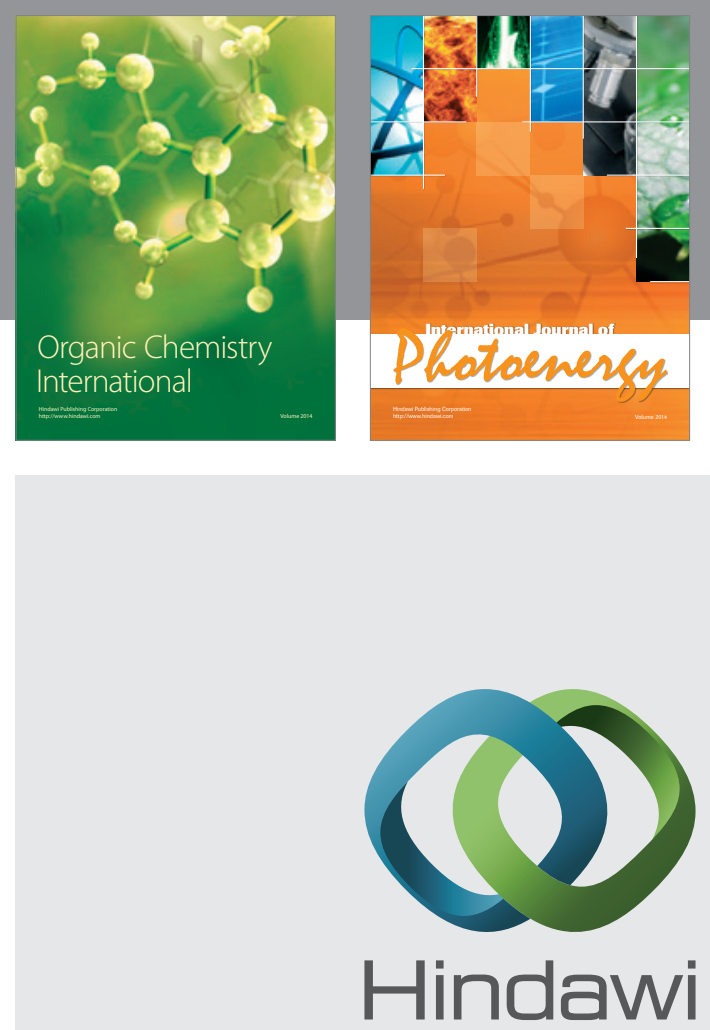

Submit your manuscripts at

http://www.hindawi.com
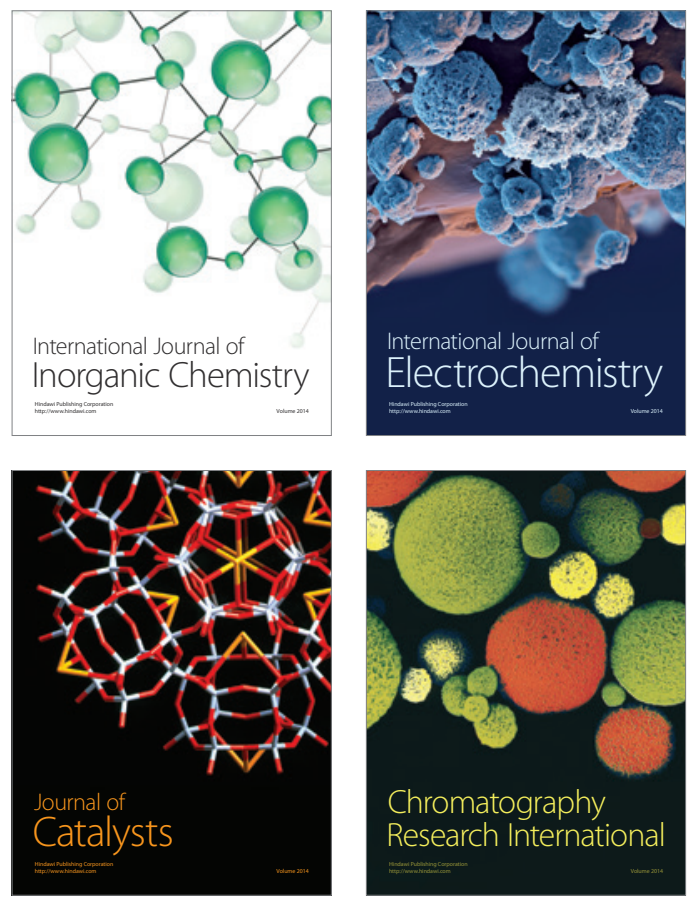
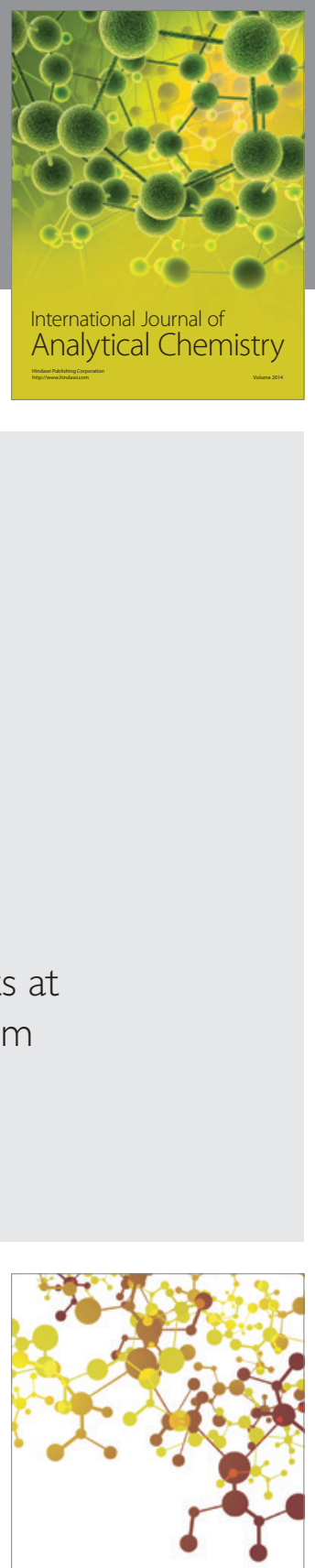

Journal of

Applied Chemistry
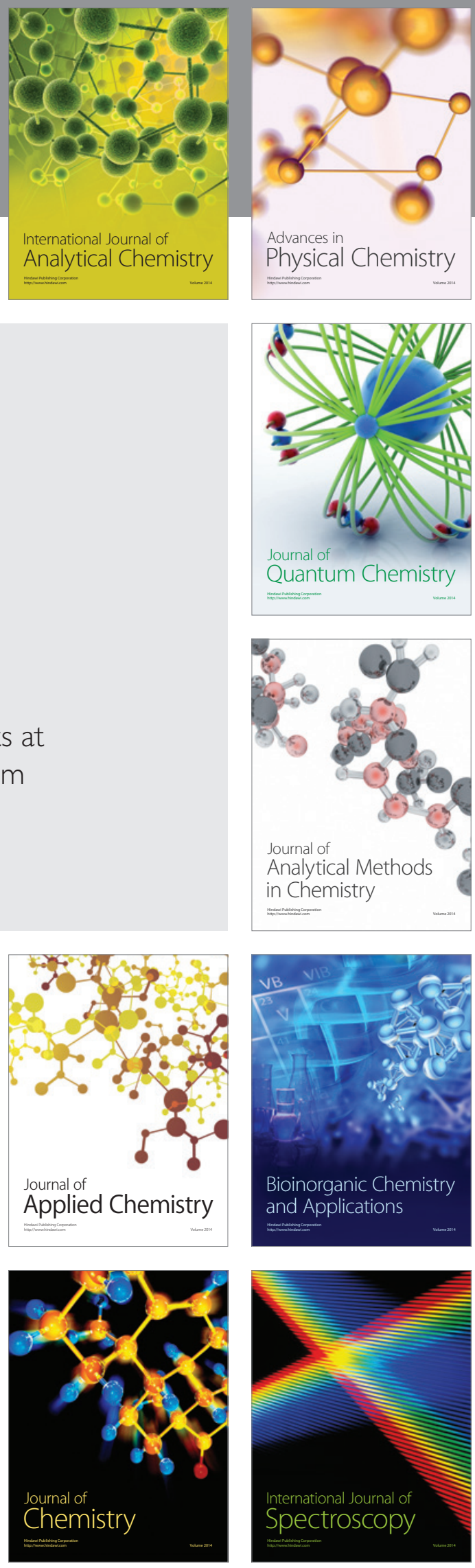